\title{
Teachers' Reflections on Teaching Mathematics in English: A Consideration for Developing ESP Course
}

\author{
Atin Kurniawati \\ UIN Raden Mas Said Surakarta \\ atin.kurniawati@iain-surakarta.ac.id
}

Article History

Received: 04 November 2021

Reviewed: 14 November 2021

Accepted: 16 November 2021

Published: 30 November 2021

Keywords: ESP, mathematics teaching, English-medium learning

\begin{abstract}
This study aims at investigating the difficulties faced by mathematics teachers in delivering learning materials in English, the strategies carried out by the teachers to overcome their problems, and its implication for ESP design. Conducted in a private school in Surakarta, which uses the Cambridge curriculum, this study involved five mathematics teachers. The data were collected by interview to elicit detailed information. Then, the data were analyzed using the interactive analysis method. Based on the study, the teachers faced several difficulties, namely vocabulary mastery, pronunciation, grammar mastery, and speaking fluency. The teachers' strategies to cope with the difficulties were improving English skills by learning from reference books and other sources, printed or online, and collaborating with peer teachers. They also used an online platform to assist their learning as well as prepare the learning media. It implied that ESP design for mathematics teachers needed to cover four aspects: vocabulary mastery, pronunciation, grammar mastery, and speaking fluency. Several platforms could be utilized to design the ESP course, including the platforms that supported the linguistic aspects and mathematical knowledge.
\end{abstract}

\section{INTRODUCTION}

English has been more widely used in Indonesian education these days, not only as a subject but also as a medium of instruction for other content subjects such as mathematics and science. It can be easily seen from the increasing number of international schools in Indonesia. In 2020, there are 509 international schools managed by both local and foreign institutions with 98.625 active students (Kementerian Pendidikan dan Kebudayaan, 2020). International schools adopt certain curriculum provided by foreign institutions. The content subjects are delivered in English as the international language. This condition results in the increasing demand for subject teachers who have good English proficiency in providing the expected learning experience. 
The growth of schools with English as a medium of instruction might be influenced by several factors, such as international recognition, improving the school reputation, and response to the globalization era. It is reported that the use of English in the country is driven by "social factors" in which parents, for example, are encouraged to enroll their kids in Englishmedium schools (Talaue \& Kim, 2020).

One of the dilemmas faced by English-medium schools in Indonesia is experienced by mathematics teachers. Teaching mathematics in English has a certain level of difficulties, such as dealing with the specific mathematical terms and expressions of learning activities that are different between Indonesian and English. Ideally, learning activity might run well if the students have mastered a certain level of language proficiency (Adoniou \& Qing, 2014). However, in the Indonesian context, in which English is considered a foreign language, classrooms usually contain students at various levels of English proficiency that might burden both the learning and communication processes. The lack of English skills results in difficulties in classroom communication (Freeman, 2012). This little communication in mathematics classrooms is evident that the medium language inhibits communication (Waswa, 2020). Therefore, mathematics teachers have an additional task to deliver all students' learning materials and ensure that the communication runs well. Teachers also sometimes face difficulty dealing with themselves, such as feeling unconfident with their English proficiency due to lack of knowledge or inadequate training in pre-service education (Othman \& Saat, 2009).

This condition is found in one public school in Surakarta, Indonesia, named SMP Islam Al Abidin, which has run two curricula, namely Kurikulum 2013 and Cambridge curriculum, since 2019. There are three subjects adopting the Cambridge curriculum: mathematics, science, and English as a second language. The students in this school attend mathematics classes delivered in English. Two aspects come into the concern. First, the mathematics teachers should adapt to the new curriculum, which should be delivered in English. The foundation provides training through several methods to improve the teachers' English skills, such as workshops, micro-teaching, and speaking clubs.

Second, there are many students with various levels of English proficiency. Some of the students who graduated from elementary school managed by the same foundation found no problems in mathematics class since they have taken the same curriculum at the previous level. However, those coming from other schools do not have adequate background in 
English. It makes the learning process slower since the teachers need to deliver the materials in a way all students can understand the concept.

Issues dealing with how and to what extent English proficiency for mathematics teachers should be developed emerged. Having a good understanding of mathematical concepts doesn't seem enough. They need pedagogical skills to help the students learn effectively. In the condition that English becomes the medium, their English competence does become another concern.

Previous researchers have conducted studies related to the use of English in mathematics classes. Ningsih (2021) conducted research and development to produce teaching and learning materials for mathematics students at Flores University. This study developed an English textbook based on need analysis and the covered topics. Dmitrenko et al. (2020) studied a theoretical substantiation and construction of autonomous learning methodology of English for Specific Purposes (ESP) course for prospective mathematics teachers. This study revealed the components of the methodological system of autonomous ESP learning, namely the main target (such as goals, objectives, social demand, and requirement); methodology (principles and approached); procedure (technologies and content); assessment (control and results).

Apsari et al. (2020) conducted a need analysis study to develop an English for mathematics textbook. This study employed a research and development method involving 27 students of the mathematics education department. Poedjiastutie (2017) studied the challenges faced by ESP courses in a private university in Malang, Indonesia. The results showed four aspects that should be applied in ESP courses but are often absent: learnercentered, authentic materials, communication focus, and practical and collaborative teaching.

The studies that have been conducted mostly took higher education context, while no study took the actual teaching and learning process at junior high school level. Students in lower levels have different characteristics from those in higher educational levels, such as background knowledge and learning experience, cognitive development, and responsibility toward the learning process. On the other hand, they also have different needs, such as material coverage. Therefore, the teachers or lecturers need different teaching strategies to meet the learners' characteristics. The requirement to use English as the medium in content subjects in elementary, secondary, and higher education levels has become an issue in Indonesia. However, studies on this field for the junior high school level are still limited. 
Therefore, this study is conducted to provide empirical experience from mathematics teachers at the junior high school level in delivering the teaching and learning materials in English

This study aims at investigating the English competence needed by mathematics teachers to deliver learning materials in English effectively. There are three focuses in this study, namely 1) the difficulties faced by mathematics teachers in delivering learning materials in English, 2) the strategies carried out by the teachers to cope with the difficulties, and 3) the implication of the teachers' reflection for ESP design. The results of this study will be beneficial in several ways. For the English department or other departments concerned with it, it gives insight for designing ESP courses for mathematics. This study reflects the real teaching experiences in the classroom. Therefore, mathematics teachers or prospective mathematics teachers can prepare their English competence better.

\section{LITERATURE REVIEW}

\section{Difficulties in Teaching Mathematics in English}

Teaching content subjects in English has become a concern in many countries. European, Asian, and African countries have started implementing English as Medium of Instruction (EMI) or Content-Language Integrated Curriculum CLIL (Uys et al., 2007). They implemented the regulation for schools from primary to higher education, varied in each country (Othman \& Saat, 2009). Mathematics is one of the content subjects delivered in English in many countries.

There are several challenges in teaching mathematics in English seen from both teachers' and students' points of view. One of the common problems is the students' and the teachers' readiness to join the class. It can be caused by two main factors, namely the students' low levels of English proficiency and the teachers' less capacity to present an effective teaching and learning process. The teachers' less capacity might affect classroom management. In addition, speaking skill is considered the hardest skill to develop, whereas this skill plays an important role in classroom communication (Poedjiastutie, 2017). This language-related issue also influences the students' performance. It is indicated that English language learners experience a disadvantage of up to $15 \%$ in mathematics because of issues with language (Riordain \& O’Donoghue, 2009).

Mathematics is considered a universal language since the operations mostly use numbers. Someone can solve mathematical problems regardless of their language background (Adoniou \& Qing, 2014). However, in fact, mathematics teachers need not only to understand 
the operation but also to deliver and explain the materials in English to their students. It comes into another challenge. Mathematics might contain words with different meanings or concepts from everyday usage or different contexts (Halladay \& Neumann, 2012). For example, the term 'root' in mathematics as in square root has a different concept from its' similar term in science as the concept about 'roots' and 'stems'.

Several strategies are employed to bring mathematical concepts easier to be understood by the students. Teachers may implement narrative or procedural contexts related to real-life applications such as sport, recipes, entertainment, transport, and technology to introduce mathematical word problems (Halladay \& Neumann, 2012). Mathematics teachers also need to ensure vocabulary for new topic areas is introduced to the students. Vocabulary is key in reading comprehension, including in mathematics. As the students went through years of schooling, they would find that mathematics vocabulary became more idiosyncratic, and the concepts became more abstract.

Another strategy to cope with the challenge in teaching mathematics in English is by implementing various learning activities appropriate to the students' condition. Even though the English terms and language expressions are different in mathematics, effective pedagogical strategies in English classrooms can also be implemented in mathematics classrooms (Halladay \& Neumann, 2012). Those strategies are, for example, reading aloud, authentic materials, teacher's silence, question and answer exercises, peer correction, and translation of literary passages (Malasari et al., 2021).

\section{English for Specific Purposes}

ESP is one of the branches of English language teaching that aims to enhance students' skills in understanding a particular use of language in a certain domain (Alsamadani, 2017). It focuses on the learners' abilities to use English for communication based on their needs. ESP generally consists of needs analysis and training for effective communication based on their field of study or work settings (Ningsih, 2021). Communication ability also includes understanding the discourse practices where the language is used and in which learners must operate (Kaewpet, 2009). Needs analysis reveals the aspects of language to study in ESP, to what extent the students need to study, and why they study the language. If it is not addressed, It will bring a challenge to teachers' identity from students or institutions (Farah, 2018). 
A study on need analysis of pre-service and in-service teachers in Europe showed that teachers need to improve theoretical and methodological aspects, teaching resources, linguistic and intercultural competence, and ongoing professional development. To best achieve the success of the English-medium learning process, the institution has to ensure that teachers are ready to teach (Cañado, 2016).

\section{METHODOLOGY}

\section{Research Design}

This study employed a qualitative approach. The data were collected by interviewing five mathematics teachers in SMP Islam Al Abidin who taught Cambridge mathematics through online platforms. The qualitative method is used to construct multiple realities explored from the perspectives of the different research participants (Poedjiastutie, 2017). The data were collected from July - August 2021. The data were then analyzed using interactive analysis based on the aims of the study till the conclusions were drawn.

\section{Respondents}

The respondents of this study were five mathematics teachers in SMP Islam Al Abidin Surakarta who taught mathematics using the Cambridge curriculum. All were women aged from 24 to 33 years old. Their mother tongue was Javanese, and none of them had lived in English-speaking countries for more than six months. They also had never joined any intensive English course conducted in at least one month. There was a weekly English program provided by the foundation and pedagogical training held on a semester basis. Based on the English proficiency test using the English Score application from British Council conducted by the foundation in December 2020, the teachers occupied the A2-B1 CEFR level of English proficiency. They had various lengths of previous teaching experience, but all respondents had taught mathematics in Cambridge class since 2019.

\section{Instruments}

Data collection techniques can be done by observation, interview, documentation, and combination/triangulation (Hardani et al., 2020). The data in this study were gained through interviews with five mathematics teachers in SMP Islam Al Abidin Surakarta. The instrument consisted of 15 questions to elicit information dealing with the topic of the study. 


\section{Procedures}

Five mathematics teachers of SMP Islam Al Abidin were contacted and explained the scope as well as the procedure of the study. All of them agreed to be respondents of this study. Then, online interviews were conducted. The responses were analyzed using the interactive analysis method.

\section{Data Analysis}

The interactive analysis of Miles and Huberman's in Amri (2021) was used in this study, consisting of four steps, namely data collection, data reduction, data presentation, and conclusion withdrawal. The data were collected through interviews. Then, the data were summarized to select the main things and focus on important points. It was to find themes and patterns that provided clearer data and helped the researcher collect and find. That was that reduction process. After that, data presentation was conducted to form a brief description, a compiled collection of information, and the possibility to draw conclusions. Drawing a conclusion was the last step after all data were complete and analyzed.

\section{FINDINGS}

Teaching mathematics in English is challenging and requires concern from the subject teachers, as elaborated in the previous sections. The level of difficulties may differ based on several factors, such as the teachers' and students' levels of English proficiency, the teachers' pedagogical competence, school facilities, etc. However, this study only focused on the teachers' point of view in delivering learning materials in English. This finding section presents the results of data analysis dealing with the teachers' difficulties and strategies in teaching mathematics in the English language, as well as their strategies to cope with it. Furthermore, the implications of the findings are presented as a consideration in developing ESP courses for mathematics teachers.

\section{Teachers' Difficulties in Teaching Mathematics in English}

As can be derived from the responses, all teachers were not confident when teaching mathematics in English because they were uncertain about their English proficiency. Meanwhile for the mastery of the materials was all fine. 
"I felt not confident because of my language. I think the material is okay." (Respondent 4)

First, they were not confident due to the lack of vocabulary or mathematical terms. Sometimes, they didn't find the equivalent concept of the mathematical term used in the Cambridge reference book in Bahasa Indonesia. They also found various terms for the same concept in English. Sometimes they found it difficult to explain the concept to the students with less English proficiency.

"The problem is the terms used are different in the reference book and website. I usually use the book term. Sometimes I found several terms for the same concept, like in Bahasa, we use pangkat. In English, the terms can be index, power, or exponent." (Respondent 1).

Second, the teachers were worried about making mistakes in pronunciation and sentence structure. Those factors somehow became a burden for their speaking fluency. The pronunciation was getting difficult because they don't usually speak or use the terms outside the classroom, and some terms were unfamiliar for them. They were also uncertain about the sentence structure. It was because they tended to arrange sentence structure based on its Indonesian translation or were uncertain of the grammatical rules. Those aspects, of course, influenced their performance when delivering the learning materials.

"What comes to my mind when I want to speak is the grammatical rules. I usually think of difficult words and complex sentences. There are also some materials that I don't quite understand. So, ya, it sometimes becomes my problem in my class." (Respondent 5)

Third, other than the language proficiency, they were also worried about the students' performance in mathematics class. They were not certain that the students could grasp the learning material they presented. It somehow could be caused by the teachers' lack of confidence in delivering the materials as well as their language and the students' less proficiency in English. The teachers noticed that the students gave a better response to classroom communication when the teachers switched to Bahasa Indonesia. 
"Teaching Cambridge class is very challenging. But somehow, it gives me the motivation to keep learning. I am sometimes afraid of making mistakes in spelling or pronunciation. I feel worried if my students don't understand my explanation or if I cannot present the materials well. Usually, they can understand better when I explain in Bahasa Indonesia, so sometimes I switch to Bahasa." (Respondent 3)

Among the three factors dealing with the difficulties in teaching mathematics using the English language, it can be derived that difficulties come from both the teachers' and the students' aspects. Somehow, briefly speaking, it was actually the teachers' aspect that was considered a more prominent factor. Their uncertainty and lack of confidence burdened their optimal performance in the teaching and learning process and influenced the students' performance. Teachers' ability to present the material in good order and appropriate language use might help the students easily grasp the learning materials.

\section{Teachers' Strategies to Cope with the Difficulties}

The difficulties faced by the mathematics teachers were mostly due to the lack of English proficiency in several aspects such as vocabulary mastery, pronunciation, and grammar mastery. Therefore, the teachers there had taken several strategies to solve the difficulties. To improve their vocabulary mastery, they checked the terms from several sources, but they were mainly concerned with those used in the Cambridge reference book.

To improve the pronunciation, they usually use an online dictionary, listen to the pronunciation from the dictionary, and then practice it. The peer teachers and English teachers at school were also helpful in correcting the pronunciation. They were aware that pronunciation played an important role in conducting the classroom instruction as well as explaining the materials. They also practiced their English by using several platforms to help them confirm the English expressions they would speak in the classroom, such as Grammarly and Flitto.

"First of all, I prepare myself and make sure that I have mastered the materials I am going to teach. I learn about the specific mathematical terms in the topic and try to pronounce them correctly. I usually watch Youtube videos to listen to how the words are pronounced or how the concept is explained. I also asked English teachers to correct my pronunciation." (Respondent 5)

"For general vocabulary, I checked my sentences in using platforms Flitto or Grammarly. For mathematical terms I refer to Cambridge term.” (Respondent 4) 
In preparing the materials, they learned from a Cambridge publisher's reference book as the curriculum's recommended book. They also took from other sources, either printed or online. There are several online learning sources for mathematics, covering the material and exercises or quizzes, such as mathisfun.com, mathgames.com, onlinemathlearning.com, and online quiz platforms.

"I use mathematics reference books from Cambridge publisher and Erlangga book. Sometimes I take the materials and learning activities such as games from some websites, mathisfun.com, mathgames.com, and onlinemathlearning.com. For quiz or evaluation, I use google form, liveworksheet, and quizziz." (Respondent 2).

Dealing with the students' responses and performance in mathematics class, they prepared themselves to master the learning materials and the English terms/sentences they were about to talk in the classroom. Proper learning presentations would make the students easier to comprehend the learning materials. As a part of their pedagogical strategies, the teachers also prepare to teach media they will use in the classroom, such as the PowerPoint file, online quiz, learning video, and devices.

"I prepare the media such as PowerPoint, note stylus pen. I also learn the materials, learn the sentences that I might use in explaining the materials, and practice my speaking if the time is enough." (Respondent 1)

The strategies seemed helpful in solving the teachers' difficulties. They employed several strategies as well as learning sources to provide a better learning experience for the students.

\section{Implications of the Findings as Consideration to Develop ESP Course}

Based on the findings, there are several implications that can be derived dealing with ESP course design. Several aspects are needed to prepare the teachers' ability to deliver mathematics materials in English, including English proficiency and preparing teaching and learning materials/media. Dealing with the ESP course, several aspects to support their proficiency should be taken into consideration, including vocabulary mastery, pronunciation, grammar mastery, and speaking fluency. Once the teachers have already comprehended those aspects, they are expected to develop a proper and effective material presentation using any media. The development of technology has enabled teachers to access various learning 
sources and activities. There are also several platforms that can be utilized for designing ESP courses, including the platforms that support linguistic aspects and mathematical knowledge.

\section{DISCUSSION}

English for Specific Purposes (ESP), especially for mathematics teachers, is one of the essential factors that contribute to the success of the learning process, especially those who teach in an international school or bilingual school, which always increase in number year by year. Being a teacher means that he needs to deliver or explain the learning materials to help the students understand the concept. There communication occurs, and language plays an important role. Since not all higher education institutions provide an adequate course for their students, the teachers often find difficulties presenting the materials in English. In this case, adequate training is urgently needed. Short (2002), as cited in Uys et al. (2007), claims that learners would probably achieve higher academic literacy if subject teachers have received adequate training that enables them to communicate effectively using four language skills and consciously develop functional language skills in the content classroom.

Based on the findings, four important aspects to consider in designing ESP courses for mathematics teachers are vocabulary mastery, pronunciation, grammar mastery, and speaking fluency. Vocabulary turns into an important factor because several specific terms in mathematics are different from daily usage. Some terms are totally new for several students who had not attended content subject delivered in English. The teachers should have learned vocabularies that they are about to use, including their word classes and form variations. Students' understanding of word families and word classes helps them understand the relation between the word concepts and the mathematical task they require. For example, 'multiple' is an adjective; 'the multiples of 10 ' is a noun; 'multiply' is a verb; 'multiplication' is a noun (Adoniou \& Qing, 2014).

On the other hand, the same concept may have different terms depending on the reference. To deal with that, the teachers need to have broader knowledge and get the students to know that those terms belong to the same concept. They need to introduce the vocabulary and its usage, as well as use it often in the teaching and learning process, so the students have a better understanding. Once the language is well-understood and often used in the mathematics classroom, learning outcomes would improve (Fuchs et al., 2012).

The second aspect is pronunciation. While previous studies focused on building the learning materials for ESP courses in mathematics (Apsari et al., 2020; Dmitrenko et al., 
2020; Ningsih, 2021; Simbolon, 2021), there was no focus on checking or improving the pronunciation in delivering the materials. ESP course in higher education institution was usually developed to assist the students in comprehending learning materials for themselves. Therefore, pronunciation practice might not get enough attention, whereas it needed a lot of training to be accustomed to.

The third aspect is grammar. Building up a well-structured sentence is an important skill for teachers in general, not only in mathematics, either spoken or written. It greatly affects the teachers' performance and results in better understanding for the students. Mathematics has certain typical language in its operation. Thus, the teachers need to recognize and introduce it to the students. Mathematics class requires more efforts to develop cognitive competencies to decode and encode mathematical problems and use appropriate mathematical language when doing so (Turner, 2011).

The fourth aspect is speaking fluency. Fluency facilitates communication; disfluent speakers have difficulties in keeping the attention of their interlocutors, which might, in turn, cause negative influences on communicative success and a failure in the interaction process (Asghar, 2021). According to Filmore (1979), as cited in Namaziandost et al. (2019), there are four criteria of speaking fluency, namely the ability to talk at a certain length without too many pauses; the ability to state coherent and meaningful sentences; having proper expressions in a wide range of contexts; having creativity and imagination in using the language.

Language proficiency affects students' performance in mathematics class. Good speaking fluency will result in better confidence. Teachers with strong confidence in teaching mathematics have a strong influence on students' motivation, particularly in the transition from upper elementary to middle school (Zee \& Koomen, 2016). Therefore, speaking courses should be a part of the ESP program for mathematics teachers. The speaking course aims at promoting the students' speaking skills to prepare them for any professional challenges they might face in their future job (Rumalessin \& Farah, 2021).

Based on the findings, the ESP course design also needs to include Information and Communication Technology (ICT) to ease the learning process. ICT, through various platforms, can assist individual learning in pronunciation, vocabulary mastery, and grammatical structure. It also assists the teachers in presenting the learning materials that can engage the students better. It is in line with previous research that learners perform positive 
attitudes toward utilizing ICT for ESP learning. The use of ICT tools is suggested in the ESP curriculum to support textbooks (Kadirolova, 2020; Keshtiarast \& Salehi, 2020).

\section{CONCLUSION}

The increased number of schools adopting international curriculum or implementing English as a medium of instruction results in the need for content teachers who are proficient in English, including mathematics subject. Since not all higher education institutions have implemented adequate ESP courses for their students, it comes into problems when the graduates have already taught in the real context. Based on the study, the mathematics teachers faced several difficulties, namely vocabulary mastery, pronunciation, grammar mastery, and speaking fluency. The teachers did several strategies to cope with the difficulties. First, they tried to improve their English fluency by learning from reference books and other sources, printed or online, and cooperating with their peer teachers. They also used an online platform to assist their learning as well as prepare the learning media. There are several implications that can be derived as a consideration in developing ESP for mathematics teachers. First, ESP design for mathematics teachers needs to cover four aspects: vocabulary mastery, pronunciation, grammar mastery, and speaking fluency. There are also several platforms that can be utilized in ESP course design, including the platforms that support linguistic aspects and mathematical knowledge.

\section{LIMITATIONS AND STUDY FORWARD}

This study only focuses on the use of English as a medium in the mathematics teaching and learning process, seen from the teachers' point of view. It does not consider other aspects such as school facilities or students' point of view. Further research may focus on developing an ESP curriculum for mathematics teaching in the junior high school context.

\section{ACKNOWLEDGEMENT}

Thanks to mathematics teachers of SMP Islam Al Abidin who had contributed as respondents in this study. 


\section{REFERENCES}

Adoniou, M., \& Qing, Y. (2014). Language, mathematics, and English language learners. Australian Mathematics Teacher, 70(3), 11-13.

Alsamadani, H. A. (2017). Needs analysis in ESP context: Saudi engineering students as a case study. Advances in Language and Literary Studies, 8(6), 58-68. https://doi.org/10.7575/aiac.alls.v.8n.6p.58

Amri, F. E. H. (2021). The lecturers' challenges and strategies in teaching English for Specific Purposes (ESP) through SPADA UNS at Sebelas Maret University [Undergraduate Thesis]. IAIN Salatiga.

Apsari, R. A., Sariyasa, Wulandari, N. P., \& Triutami, T. W. (2020). Analisis kebutuhan pengembangan buku ajar English for mathematics. Jurnal Pendidikan Dan Kebudayaan Missio, 12(2), 80-86. https://doi.org/10.36928/jpkm.v12i2.384

Asghar, A. (2021). Developing EFL learners' speaking fluency: use of practical techniques. MEXTESOL Journal, 45(2), 1-13.

Cañado, María L. P. (2016). Are teachers ready for CLIL? Evidence from a European study. European Journal of Teacher Education, 39(2), 202-221. https://doi.org/10.1080/02619768.2016.1138104

Dmitrenko, N., Nikolaeva, S., Melnyk, L., \& Voloshyna, O. (2020). Autonomous ESP learning of prospective teachers of mathematics. Romanian Journal for Multidimensional Education, 12(1), 86-104.

Farah, R. R. (2018). 'Who am I?' Interrogating my identity as ESP teacher: personal narration. A Journal of Culture English Language Teaching Literature \& Linguistics, $3(1), 1-14$.

Freeman, B. (2012). Using digital technologies to redress inequities for English language learners in the English speaking mathematics classroom. Computers \& Education, 59(1), 50-62. https://doi.org/10.1016/j.compedu.2011.11.003

Fuchs, L. S., Fuchs, D., \& Compton, D. L. (2012). The early prevention of mathematics difficulty: its power and limitations. Journal of Learning Disabilities, 45(3), 257-269. https://doi.org/10.1177/0022219412442167

Halladay, J. L., \& Neumann, M. D. (2012). Connecting reading and mathematical strategies. The Reading Teacher, 65(7), 471-476. https://doi.org/10.1002/TRTR.01070

Hardani, H., Andriani, H., Istiqomah, R. R., \& Ustiawaty, J. (2020). Buku metode penelitian kualitatif \& kuantitatif. CV. Pustaka Ilmu Group.

Kadirolova, L. M. (2020). The importance of using ICT in ESP teaching. European Journal of Research and Reflection in Educational Sciences, 8(3), 145-148. 
Kaewpet, C. (2009). A Framework for investigating learner needs: needs analysis extended to curriculum development. Electronic Journal of Foreign Language Teaching, 6(2), 209-220.

Kementerian Pendidikan dan Kebudayaan. (2020). Data SPK tahun ajaran 2019/2020. eLayanan SPK Direktorat Jenderal Pendidikan Anak Usia Dini Pendidikan Dasar dan Menengah. https://e-layanan.dikdasmen.kemdikbud.go.id/newspk/

Keshtiarast, B., \& Salehi, H. (2020). Investigating employing information communication technology for ESP learning: A case of Iranian EFL students' attitudes. International Online Journal of Education and Teaching, 7(2), 412-433.

Malasari, S., Kurniawati, L. A., \& Martanti, I. F. R. (2021). Students' perceptions on the implementation of blended learning in English for mathematics. Metathesis: Journal of English Language, Literature, and Teaching, 4(3), 292-305. https://doi.org/10.31002/metathesis.v4i3.3314

Namaziandost, E., Hashemifardnia, A., \& Shafiee, S. (2019). The impact of opinion-gap, reasoning-gap, and information-gap tasks on EFL learners' speaking fluency. Cogent Social Sciences, 5(1), 1630150. https://doi.org/10.1080/23311886.2019.1630150

Ningsih, N. (2021). Developing English teaching and learning materials for mathematics study program. Edukatif: Jurnal Ilmu Pendidikan, 3(4), 1112-1119. https://doi.org/10.31004/edukatif.v3i3.501

Othman, J., \& Saat, R. M. (2009). Challenges of using English as a medium of instruction: pre-service science teachers' perspective. The Asia-Pacific Education Researcher, 18(2), 307-316. https://doi.org/10.3860/taper.v18i2.1331

Poedjiastutie, D. (2017). The pedagogical challenges of English for specific purposes (ESP) teaching at the University of Muhammadiyah Malang, Indonesia. Educational Research and Reviews, 12(6), 338-349. https://doi.org/10.5897/ERR2016.3125

Riordain, M. N., \& O’Donoghue, J. (2009). The relationship between performance on mathematical word problems and language proficiency for students learning through the medium of Irish. Educational Studies in Mathematics, 71(1), 43-64. https://doi.org/10.1007/s10649-008-9158-9

Rumalessin, U. A. T., \& Farah, R. R. (2021). Investigating the English needs of law department students in English for specific purposes. JEES (Journal of English Educators Society), 6(1), 126-132. https://doi.org/10.21070/jees.v6i1.1085

Simbolon, N. E. (2021). English Medium Instruction (EMI) practice: higher education internationalization in Indonesia. Englisia: Journal of Language, Education, and Humanities, 8(2), 72-83. https://doi.org/10.22373/ej.v8i2.8961

Talaue, F. G., \& Kim, M. K. (2020). Investigating the advantages of English Medium Instruction (EMI) in the Indonesian workplace. Language Education and Acquisition Research Network Journal, 13(2), 321-334. 
Turner, R. (2011). Identifying cognitive processes important to mathematics learning but often overlooked. Australian Mathematics Teacher, 67(2), 22-26.

Uys, M., van der Walt, J., van den Berg, R., \& Botha, S. (2007). English medium of instruction: a situation analysis. South African Journal of Education, 27(1), 69-82.

Waswa, D. W. (2020). The effects and implications of the use of English as a medium of instruction in mathematics on Thai learners. International Journal of Social Sciences \& Educational Studies, 7(2), 89-107. https://doi.org/10.23918/ijsses.v7i2p89

Zee, M., \& Koomen, H. M. Y. (2016). Teacher self-efficacy and its effects on classroom processes, student academic adjustment, and teacher well-being: a synthesis of 40 years of research. Review of Educational Research, 86(4), 981-1015. https://doi.org/10.3102/0034654315626801 